\title{
WHAT IS BEHIND BIASED TECHNICAL CHANGE IN PRODUCTION OF CEREAL AND OILSEED CROPS IN SLOVAKIA?
}

\author{
Peter FANDEL
}

Address:

Slovak University of Agriculture in Nitra, Faculty of Economics and Management, Department of Statistics and Operations Research, Tr.A.Hlinku 2, 94976 Nitra, Slovakia; e-mail: peter.fandel@uniag.sk

\begin{abstract}
This study investigates the productivity change in the production of cereal and oilseed crops in Slovakia with special emphasis on technical change analysis. It employs a non-parametric distance function approach to measure Malmquist productivity index which is decomposed into technical efficiency change and technical change. Technical change is further decomposed into technical change magnitude and input- and output-bias indices. The productivity change components provide more detailed information about character of productivity change itself and its sources. Our results indicate that productivity in the analysed sector decreased approximately by $20 \%$ within the examined period of 1998-2007. The decrease was caused mostly by worsening the technical change (-41.6\%). Indices of input- and output bias of technical change were various from unity what suggests that technical change was not Hicks'- neutral. Results of further analysis of the direction of technical change bias indicate that farms in average tend to apply fertilizers-using/seed-saving, seed-using/labour-saving, and fertilizers-using/labour-saving technical change bias over the whole sample period, as well as in the EU pre-accession and EU post-accession periods.
\end{abstract}

Keywords: Malmquist index, technical efficiency change, technical change, output bias, input bias, magnitude of technical change

JEL: C43, D24, Q12

\section{INTRODUCTION}

In recent years several papers were published on productivity growth in agriculture employing nonparametric methods based on Data Envelopment Analysis (DEA). There are several analyses done on macro data of EU countries (Galanopoulos, Kragiannis, Koutroumanidis, 2004), developed and developing countries (Trueblood, Coggins, 2003; Fulginiti, Perrin, 1997), or country provinces (Nin, Arndt, Preckel, 2003). Several works are based on micro data: Latruffe et al. (2012) and Sipiläinen \& Kumbhakar (2010) examined productivity change of dairy farms in EU countries; Sipiläinen \& Rihänen (2005) focused on silage producers in Finland; Latruffe \& Fogarasi (2009) investigated productivity change differences of mixed farms in France and Hungary. In the above referenced studies Malmquist index of total factor productivity change is used as a basic indicator. It is frequently decomposed into technical efficiency change index and technical change index. Both components illustrate what is the source of productivity change, whether it is efficiency catch-up or technological progress as a result of innovation. Widely used is also decomposition of technical efficiency change to pure efficiency change and scale efficiency change, which give an indication of whether farms improve their productivity by better management, or by a shift to the most productive scale size (see e.g. Wu et al, 2001, Lissitsa Rungsuriyawiboon, 2006). Relatively new and in literature still debated (Lovell, 2003) is the methodological approach focusing on decomposition of technical change to the components that enable evaluate technical change bias, i.e. proportionality of changes of output isoquants at different mixes of inputs, or proportionality of changes of input isoquants at different output mixes. This property is a prerequisite for assessing whether technical change is Hicks'-neutral, or Hicks'biased. Applications can be found in transportation sector (Barros, Weber, 2009), bank sector (Barros, Managi, Matousek, 2009), in education (Barros, Guironnet, Peypoch, 2011), and in international comparisons (Chen, Yu, 2012).

In this paper an attempt is made to examine the productivity change and its components in the sector of production of cereal and oilseed crops in Slovakia in the period 1998-2007. Special motivation is to learn what is behind the high technical regress. Both, cereals and oilseed crops are cultivated using very similar technology and it is the reason we treat them together. Within the period examined they created ca $75 \%$ share on arable land in Slovakia and are considered as a stable part in farm production structure. In the period 1998-2007 Slovak agriculture mostly finished transformation to a 
market oriented economy and Slovak Republic has joined European Union. Both facts had a significant impact on the farming sector, resulting in the reduction of subsidies from the government budget, more tough international competition, higher food imports, and an access to support funds of EU within Common Agricultural Policy (Bartošová, Bartová, Fidrmuc, 2007). We are trying to link estimated productivity change indicators to the mentioned factors.

The paper itself is divided into five main sections. The second section focuses on the theoretical background to the indexes of productivity and technical change employed. The third section deals with the specification of inputs and outputs employed in the evaluation of technical efficiency and technical change in the sector of cereals and oilseeds. The fourth section presents the resultant indices of productivity, efficiency, and technical change and their components. The paper ends with some brief concluding remarks in the final section.

\section{MATERIAL AND METHODS}

\section{Malmquist index of total factor productivity change and} its components

Malmquist index of productivity change is an indicator enabling to measure productivity change of several factors between two adjacent periods. Malmquist index employs Shephard's distance functions.

Output oriented distance function for the period $t$ defined by Shephard (1970) is:

$D_{o}^{t}\left(x^{t}, y^{t}\right)=\inf \left\{\theta:\left(x^{t}, \frac{y^{t}}{\theta}\right) \in S^{t}\right\}, t, \ldots T$

where inf is an operator for infimum, $\theta$ is a scalar, $x^{t}=$ $\left(x_{1}^{t}, \ldots x_{M}^{t}\right) \in \Re_{+}^{M}$ is a vector of inputs and $y^{t}=$ $\left(y_{1}^{t}, \ldots y_{S}^{t}\right) \in \mathfrak{R}_{+}^{S}$ is a vector of outputs in time period $t$. Expression $\mathrm{S}^{t}$ represents a technology in time period $t$, which defines the transformation of inputs to outputs and shows the set of all feasible input-output vectors:

$S^{t}=\left\{\left(x^{t}, y^{t}\right): x^{t}\right.$ can produce $\left.y^{t}\right\}, t=1, \ldots T$.

Output sets in accordance with $\mathrm{S}^{t}$ are defined as follows:

$P^{t}\left(x^{t}\right)=\left\{y^{t}:\left(y^{t}, x^{t}\right) \in S^{t}\right\}, t=1, \ldots, T$.

Distance function $D_{o}^{t}\left(x^{t}, y^{t}\right)$ expresses maximal radial proportional expansion of output vector at the given level of input vector.

Among other properties, the output distance function satisfies the inequality

$D_{o}^{t}\left(x^{t}, y^{t}\right) \leq 1$, with

$D_{o}^{t}\left(x^{t}, y^{t}\right)=1$ if and only if $y^{t} \in$ Isoq $P^{t}\left(x^{t}\right)=$ $\left\{y^{t}: y^{t} \in P^{t}\left(x^{t}\right), \theta y^{t} \notin P^{t}\left(x^{t}\right), \theta>1\right\}$

Caves, Christensen and Diewert (1982) suggested Malmquist index as a ratio of two output distance functions for period $t$ and $t+1$ relative to technology $\mathrm{S}^{t}$

$M_{o}^{t}=\frac{D_{o}^{t}\left(x^{t+1}, y^{t+1}\right)}{D_{o}^{t}\left(x^{t}, y^{t}\right)}$

Färe, Grosskopf, Lindgren and Roos (1989, 1994) inspired by Caves, Christensen and Diewert (1982) defined output oriented Malmquist index as the geometric mean of two Malmquist indexes for two adjacent periods $t$ and $t+1$, using reference technology $\mathrm{S}^{t}$, as well as technology $\mathrm{S}^{t+1}$.

$$
\begin{aligned}
& M_{o}\left(x^{t}, y^{t}, x^{t+1}, y^{t+1}\right)= \\
& {\left[\frac{D_{o}^{t}\left(x^{t+1}, y^{t+1}\right)}{D_{o}^{t}\left(x^{t}, y^{t}\right)} \frac{D_{o}^{t+1}\left(x^{t+1}, y^{t+1}\right)}{D_{o}^{t+1}\left(x^{t}, y^{t}\right)}\right]^{\frac{1}{2}}}
\end{aligned}
$$

With regard to character of employed distance functions Malmquist index $M_{o}\left(x^{t}, y^{t}, x^{t+1}, y^{t+1}\right) \gtreqless 1$, according as productivity change between two periods $t$ and $t+1$ can be positive, zero or negative.

According Färe, Grosskopf, Lindgren and Roos (1989, 1994) Malmquist index (3) can be decomposed to technical efficiency change (TECH) and technical (technological) change (TCH). Following Fare et al. $(1989,1994)$ an equivalent way of writing this index is:

$$
\begin{aligned}
& M_{o}\left(x^{t}, y^{t}, x^{t+1}, y^{t+1}\right) \\
= & \frac{D_{o}^{t+1}\left(x^{t+1}, y^{t+1}\right)}{D_{o}^{t}\left(x^{t}, y^{t}\right)}\left[\frac{D_{o}^{t}\left(x^{t+1}, y^{t+1}\right)}{D_{o}^{t+1}\left(x^{t+1}, y^{t+1}\right)} \frac{D_{o}^{t}\left(x^{t}, y^{t}\right)}{D_{o}^{t+1}\left(x^{t}, y^{t}\right)}\right]^{\frac{1}{2}} \\
= & \operatorname{TECH}\left(x^{t}, y^{t}, x^{t+1}, y^{t+1}\right) . \operatorname{TCH}\left(x^{t}, y^{t}, x^{t+1}, y^{t+1}\right)
\end{aligned}
$$

where $\mathrm{TECH}>1$ indicates improvement in technical efficiency and $\mathrm{TECH}<1$ deterioration in technical efficiency. TCH $>1$ indicates technical progress (evidence of innovation) and $\mathrm{TCH}<1$ technical regress. Both components equal unity are associated with no change. Likewise Malmquist index of total factor productivity change equal unity means stagnation, index greater that unity indicates growth and index less that unity means deterioration of productivity.

Malmquist index in (3) a (4) is based on the assumption that technology exhibits constant returns to scale (CRS). If the assumption on returns to scale is relaxed to allow variable returns to scale (VRS), then component of TECH in (4), following Färe, Grosskopf, Lovell (1994), can be further decomposed to scale efficiency change $(\mathrm{SECH})$ and pure efficiency change $(\mathrm{PECH})$ :

$\operatorname{TECH}\left(x^{t}, y^{t}, x^{t+1}, y^{t+1}\right)$

$=\left[\frac{D_{o}^{t}\left(x^{t}, y^{t} \mid V R S\right)}{D_{o}^{t}\left(x^{t}, y^{t} \mid C R S\right)} \frac{D_{o}^{t+1}\left(x^{t+1}, y^{t+1} \mid C R S\right)}{D_{o}^{t+1}\left(x^{t+1}, y^{t+1} \mid V R S\right)}\right]$

$\left[\frac{D_{o}^{t+1}\left(x^{t+1}, y^{t+1} \mid V R S\right)}{D_{o}^{t}\left(x^{t}, y^{t} \mid V R S\right)}\right]$

$=\operatorname{SECH}\left(x^{t}, y^{t}, x^{t+1}, y^{t+1}\right) \cdot \operatorname{PECH}\left(x^{t}, y^{t}, x^{t+1}, y^{t+1}\right)$

Changes in inputs structure in favour of technologically more advanced and effective inputs may lead to biases, which may result in non-proportional shifts of input isoquants. One possible way how to evaluate those changes is to decompose technical change to output bias of technical change $(\mathrm{OBTCH})$ index, input bias of technical change (IBTCH) index and the magnitude of technical change (MTCH) (Färe, GrifelTatjé, Grosskopf, Lovell, 1997):

$\operatorname{TCH}\left(x^{t}, y^{t}, x^{t+1}, y^{t+1}\right)=$ 
$\left[\frac{D_{o}^{t}\left(x^{t+1}, y^{t+1}\right)}{D_{o}^{t+1}\left(x^{t+1}, y^{t+1}\right)} \frac{D_{o}^{t+1}\left(x^{t+1}, y^{t}\right)}{D_{o}^{t}\left(x^{t+1}, y^{t}\right)}\right]^{\frac{1}{2}}\left[\frac{D_{o}^{t+1}\left(x^{t}, y^{t}\right)}{D_{o}^{t}\left(x^{t}, y^{t}\right)} \frac{D_{o}^{t}\left(x^{t+1}, y^{t}\right)}{D_{o}^{t+1}\left(x^{t+1}, y^{t}\right)}\right]^{\frac{1}{2}} \times$ $\left[\frac{D_{o}^{t}\left(x^{t}, y^{t}\right)}{D_{o}^{t+1}\left(x^{t}, y^{t}\right)}\right]=\mathrm{OBTCH} * \mathrm{IBTCH} * \mathrm{MTCH}$

Output bias shows whether input isoquant shifts non-proportionally for various outputs combinations and input bias indicates whether output isoquant shifts nonproportionally for various input mixes. Technical change is Hicks'-output (input) neutral, resp. does not comprise any bias if both OBTCH and IBTCH are equal unity. Under the assumption of both neutralities, both OBTCH and IBTCH are equal unity and $\mathrm{MTCH}$ component is equal $\mathrm{TCH}$, i.e. all technical change is comprised in technical change itself.

Following Fare et al. (2001) and Barros and Weber (2009) we calculate alternative directions of technical change input bias as it is shown in Table 1.

Table 1: Input biased technical change and changes in the input mix

\begin{tabular}{llll}
\hline Input mix & IBTCH $>1$ & IBTCH $<1$ & IBTCH=1 \\
\hline$\left(\frac{x_{r}}{x_{s}}\right)^{t+1}>\left(\frac{x_{r}}{x_{s}}\right)^{t}$ & $x_{r}-$ using, & $x_{s}-$ using, & Neutral \\
$x_{s}-$ saving & $x_{r}-$ saving & \\
$\left(\frac{x_{r}}{x_{s}}\right)^{t+1}<\left(\frac{x_{r}}{x_{s}}\right)^{t}$ & $x_{s}-$ using, & $x_{r}-$ using, & Neutral \\
& $x_{r}-$ saving & $x_{s}-$ saving & \\
\hline
\end{tabular}

The fact that distance function $D_{o}^{t}\left(x^{t}, y^{t}\right)$ is reciprocal to Farrell (1957) technical efficiency measure, led Färe, Grosskopf, Lindgren and Roos $(1989,1994)$ to suggestion to employ Data Envelopment Analysis to its estimation.

Estimation of distance function values for components calculation needs to apply 8 DEA models for each decision making unit, list of which is presented in Table 2.

\section{Data}

Data for the study are drawn from nationally representative sample of the Ministry of Agriculture (information sheets on farms). In the analysis panel data representing 422 farms for the period 1998-2007 has been used in following structure: 104 commercial farms and 338 cooperative farms.

For the purposes of subsequent analysis, we categorise farm data into two groups: data representing EU pre-accession years 1998-2003 and data representing EU post-accession years 2004-2007.

Total acreage of the farms examined in the study makes more than $51 \%$ of the total arable land in Slovakia.

Two output- and three input variables have been used in the estimation of production frontier:

- output 1: cereals and oilseed production (tons)

- output 2: crop sales (thous. SKK)

- input 1: fertilizers costs (thous. SKK)

- input 2: seed costs (thous. SKK)

- input 3: labour costs (thous. SKK)

Table 3 shows descriptive statistics of the variables for the year 2007. Descriptive statistics for all sample years 1998-2006 is presented in the Appendix 1.
Table 2: DEA models for distance functions estimation

$\begin{array}{ll}\text { Model 1 } & \text { Model 2 } \\ {\left[\mathrm{D}_{\mathrm{o}}^{\mathrm{t}}\left(x^{t}, y^{t} \mid C R S\right)\right]^{-1}} & {\left[\mathrm{D}_{\mathrm{o}}^{\mathrm{t}}\left(x^{t}, y^{t} \mid V R S\right)\right]^{-1}} \\ =\max _{\varphi, \lambda} \varphi & \end{array}$

subject to

$$
\begin{aligned}
\varphi y_{j}^{t}-Y^{t} \lambda \leq 0 \\
X^{t} \lambda \leq x_{j}^{t} \\
\lambda \geq 0
\end{aligned}
$$

$$
\begin{aligned}
\varphi y_{j}^{t}-Y^{t} \lambda \leq 0 \\
X^{t} \lambda \leq x_{j}^{t} \\
\lambda \geq 0 \\
1^{\prime} \lambda=1
\end{aligned}
$$

$$
\begin{aligned}
& \text { Model } 3 \\
& {\left[\mathrm{D}_{\mathrm{o}}^{\mathrm{t}+1}\left(x^{t+1}, y^{t+1} \mid C R S\right)\right]^{-1}} \\
& =\max _{\varphi, \lambda} \varphi
\end{aligned}
$$

Model 4

subject to

$$
\begin{array}{r}
{\left[\mathrm{D}_{\mathrm{o}}^{\mathrm{t}+1}\left(x^{t+1}, y^{t+1} \mid V R S\right)\right]^{-1}} \\
=\max _{\varphi, \lambda} \varphi
\end{array}
$$

$$
\begin{aligned}
\varphi y_{j}^{t+1}-Y^{t+1} \lambda & \leq 0 \\
X^{t+1} \lambda & \leq x_{j}^{t+1} \\
\lambda & \geq 0
\end{aligned}
$$

subject to

$$
\begin{aligned}
\varphi y_{j}^{t+1}-Y^{t+1} \lambda & \leq 0 \\
X^{t+1} \lambda & \leq x_{j}^{t+1} \\
\lambda & \geq 0 \\
1^{\prime} \lambda & =1
\end{aligned}
$$

$$
\begin{array}{r}
\text { Model 5 } \\
{\left[\mathrm{D}_{\mathrm{o}}^{\mathrm{t}}\left(x^{t+1}, y^{t+1} \mid C R S\right)\right]^{-1}} \\
=\max _{\varphi, \lambda} \varphi \\
\text { subject to } \\
\varphi y_{j}^{t+1}-Y^{t} \lambda \leq 0 \\
X^{t} \lambda \leq x_{j}^{t+1} \\
\lambda \geq 0
\end{array}
$$

$$
\text { Model } 6
$$$$
\left[\mathrm{D}_{\mathrm{o}}^{\mathrm{t}+1}\left(x^{t}, y^{t} \mid C R S\right)\right]^{-1}
$$

$\max _{\varphi, \lambda} \varphi$

subject to

subject to

$$
\begin{aligned}
\varphi y_{j}^{t}-Y^{t} \lambda \leq 0 \\
X^{t} \lambda \leq x_{j}^{t+1} \\
\lambda \geq 0
\end{aligned}
$$$$
=\max _{\varphi, \lambda} \varphi
$$

$$
\begin{array}{r}
\varphi y_{j}^{t}-Y^{t+1} \lambda \leq 0 \\
X^{t+1} \lambda \leq x_{j}^{t} \\
\lambda \geq 0
\end{array}
$$

$$
\begin{aligned}
& \text { Model } 8 \\
& {\left[\mathrm{D}_{\mathrm{o}}^{\mathrm{t}+1}\left(x^{t+1}, y^{t} \mid C R S\right)\right]^{-1}} \\
& =\max _{\varphi, \lambda} \varphi
\end{aligned}
$$

subject to

$$
\begin{aligned}
\varphi y_{j}^{t}-Y^{t+1} \lambda & \leq 0 \\
X^{t+1} \lambda & \leq x_{j}^{t} \\
\lambda & \geq 0
\end{aligned}
$$

\section{Notation:}

$y_{j}^{t}$ is $\mathrm{S} \times 1$ vector of outputs of $\mathrm{j}$-th $\mathrm{DMU}$ in period $\mathrm{t}$

$x_{j}^{t}$ is $\mathrm{M} \times 1$ vector of inputs of $\mathrm{j}$-th DMU in period $\mathrm{t}$

$Y^{t}$ is $\mathrm{S} \times \mathrm{N}$ matrix of $\mathrm{S}$ outputs and $\mathrm{N}$ DMUs in a period $\mathrm{t}$

$X^{t}$ is $\mathrm{M} \times \mathrm{N}$ matrix of $\mathrm{M}$ inputs and $\mathrm{N}$ DMUs in a period $\mathrm{t}$

$\lambda$ is $N \times 1$ vector of intensity variables

$\varphi$ is scalar, output oriented measure of efficiency

\section{RESULTS AND DISCUSSION}

In this section, we present summary description of average and cumulative performance indices for all 422 farms within 10 year horizon. Table 4 presents geometric mean estimates of productivity change and its components for the pooled farms by year, geometric mean for the whole period and cumulative indices. Values of Malmquist index, technical efficiency change, pure efficiency change, scale efficiency change, and technical change greater than one indicate productivity gains, increases in efficiency, or technological progress. Values of input-biased technical change, output-biased technical change, and magnitude of technical change different from one indicate that technical change is not Hicks' neutral. 
Table 3: Descriptive statistics of the data, year 2007

\begin{tabular}{lcrrr}
\hline Variable & Mean & $\begin{array}{c}\text { Standard } \\
\text { deviation }\end{array}$ & Minimum & Maximum \\
\hline $\begin{array}{l}\text { Fertilizers costs } \\
\text { [thous. SKK] }\end{array}$ & 3332 & 3452 & 16 & 28880 \\
$\begin{array}{l}\text { Seed costs } \\
\text { [thous. SKK] }\end{array}$ & 2931 & 2644 & 47 & 20623 \\
$\begin{array}{l}\text { Labour costs } \\
\text { [thous. SKK] }\end{array}$ & 7529 & 7029 & 3 & 43851 \\
$\begin{array}{l}\text { Cereals and oilseed } \\
\text { production [tons] }\end{array}$ & 3208 & 3089 & 14 & 24365 \\
$\begin{array}{l}\text { Crop sales } \\
\text { [thous. SKK] }\end{array}$ & 21036 & 21155 & 2 & 146112 \\
\hline Data: VÚEPP Bratislava, table: author's calculation & &
\end{tabular}

We can see that within the whole period 19982007 productivity $\left(\mathrm{M}_{\mathrm{o}}\right)$ decreased by more than $20 \%$. Average yearly decrease was $2.5 \%$. Most significant year-to-year falls in productivity are seen in years 2000 and 2003. They were caused evidently by very low precipitation totals and serious drought devastating agricultural crops in the majority of Slovakia (Sekáčová, Št'astný, Lapin, 2004; MPaRV SR, 2000, 2003). On the other hand $56.4 \%$ productivity increase in 2004 was a result of favorable growing conditions. Only $29 \%$ farms of the sample period were able to increase their productivity.

Decrease of productivity was mitigated by improvement of technical efficiency (TECH) by almost $37 \%$ within the whole period. Improvement of technical efficiency was probably invoked by more tough competition within the sector and at the market. Almost $82 \%$ farms improved their $\mathrm{TECH}$ within the sample period.

Decomposition of TECH indicates that improvement of technical efficiency in our sample was caused predominantly by improvement of pure technical efficiency (PECH) - approximately by $27 \%$, and to certain extends by improvement of scale efficiency $(\mathrm{SECH})-$ more that $7 \%$. Improvement in $\mathrm{PECH}$ is usually interpreted as an improvement in management of production. SECH increase may be a result of the fact that farms are approaching the optimal scale size for the sector of cereals and oilseed crops production.

Productivity decrease was caused mostly by negative technical change (TCH) - almost $42 \%$ within the whole period. It may indicate lack of innovation in production technology, mainly as far as the absence of introduction of new crop varieties resistant to weather extremes, and production processes minimizing impact of negative natural conditions.

The technical change part of the Malmquist index consists of the indices of magnitude (neutral) change, input-biased change and output-biased change of the technology. These components reflect intertemporal movements of the best practice frontier. Our results in Table 4 show that average input-biased technical change equals 1.022. Since it is different form one it indicates that technical change in this sector cannot be assumed Hicks' - neutral.
Cumulative index of magnitude of technical change $(\mathrm{MTCH}=0.392)$ for the sample period indicates significant neutral technology regress.

In the Table 4 we present also comparison of the EU pre-accession period to the EU post-accession period average cumulative indices of productivity and its components. Better results in favour of post-accession period were found as far as the $\mathrm{M}_{\mathrm{o}}, \mathrm{TECH}, \mathrm{PECH}, \mathrm{TCH}$, and $\mathrm{MTCH}$. Worse results were found in SECH. All differences are statistically significant. It can lead to conclusion that EU accession had a positive impact on farm performance in the sector. Only scale efficiency change has deteriorated by more than 2 percentage points.

Further we provide results of a more detailed investigation of the direction of technical change through the analysis of the bias direction and input ratios. In Table 5 we summarise the number of farms that experience a bias in the use of inputs. Farms are distributed according to three classes of IBTCH values. Except year 2001/2000 in all years farms with IBTCH $>1$ prevail.

Recall that in the analysis ratios of three inputs are considered, fertilizers (F), seed (S), and labour (L). There are three combinations of the inputs, F vs. S, S vs. L, and $\mathrm{F}$ vs. L to identify the bias direction. With respect to rules in Table 1 if $\mathrm{x}_{\mathrm{r}} / \mathrm{x}_{\mathrm{s}}$ increases, then IBTCH $>1$ implies $\mathrm{x}_{\mathrm{r}}$-using bias and IBTCH $<1$ implies $\mathrm{x}_{\mathrm{S}}$-using bias. If $\mathrm{x}_{\mathrm{r}} / \mathrm{x}_{\mathrm{S}}$ decreases, then IBTCH $>1$ implies $x_{\mathrm{s}}$-using bias and IBTCH $<1$ implies $\mathrm{X}_{\mathrm{r}}$-using bias.

According to Table 5 technical change bias indicates that producers generally do not tend to follow any factor using/saving pattern over the examined period. Distribution of farms within the sample period shows significant changes in some years. Average numbers show that majority of farms follow fertilizers-using/seedsaving, seed-using/labour-saving, and fertilizersusing/labour-saving technical change bias.

According to average values of IBTCH and input mix ratios, shown in Table 6 , in the sample period farms experience fertilizers-using bias as compared with the use of seed. The same pattern is seen also in preaccession period, as well as in post-accession period. For the input pair of seed versus labour, for all three periods, pattern of seed-using/labour-saving bias is estimated. The last input mix pair - fertilizers vs. labour exhibits fertilizers-using and labour saving bias for all three periods.

Great variability of IBTCH and input bias orientation in year-to-year development does not allow concluding on any statistically significant using-saving pattern.

\section{CONCLUSIONS}

The objective of the paper was to analyse productivity change in the sector of cereals and oilseed production in Slovakia and to examine its development from the aspects of its components in the period 1998-2007. 
Table 4: Malmquist productivity index and its components, 1998-2007

\begin{tabular}{lrrrrrrrr}
\hline Year & $\mathrm{M}_{0}$ & TECH & PECH & SECH & TCH & IBTCH & OBTCH & MTCH \\
\hline $1999 / 1998$ & 1.030 & 1.098 & 1.056 & 1.040 & 0.937 & 1.037 & 1.026 & 0.881 \\
$2000 / 1999$ & 0.772 & 1.082 & 1.067 & 1.015 & 0.713 & 1.012 & 1.009 & 0.699 \\
$2001 / 2000$ & 1.297 & 0.982 & 0.949 & 1.034 & 1.321 & 1.010 & 1.013 & 1.290 \\
$2002 / 2001$ & 0.983 & 1.100 & 1.138 & 0.967 & 0.894 & 1.025 & 1.007 & 0.866 \\
$2003 / 2002$ & 0.694 & 0.903 & 0.905 & 0.997 & 0.769 & 1.042 & 1.031 & 0.715 \\
$2004 / 2003$ & 1.564 & 1.165 & 1.176 & 0.990 & 1.343 & 1.041 & 1.066 & 1.210 \\
$2005 / 2004$ & 0.917 & 0.826 & 0.932 & 0.885 & 1.111 & 1.002 & 1.001 & 1.108 \\
$2006 / 2005$ & 0.857 & 1.114 & 0.966 & 1.153 & 0.769 & 1.007 & 1.030 & 0.742 \\
$2007 / 2006$ & 0.924 & 1.101 & 1.091 & 1.009 & 0.839 & 1.018 & 1.028 & 0.801 \\
Geom.mean (GM) & 0.975 & 1.035 & 1.027 & 1.008 & 0.942 & 1.022 & 1.023 & 0.901 \\
GM 1998-2003 & 1.016 & 1.051 & 1.044 & 1.007 & 0.966 & 1.028 & 1.025 & 0.917 \\
GM 2004-2007 & 0.899 & 1.004 & 0.994 & 1.010 & 0.895 & 1.009 & 1.019 & 0.870 \\
Cumulative index (CI) & 0.799 & 1.368 & 1.272 & 1.073 & 0.584 & 1.212 & 1.229 & 0.392 \\
CI 1998-2003 & 0.704 & 1.159 & 1.101 & 1.052 & 0.607 & 1.133 & 1.089 & 0.492 \\
CI 2004-2007 & 1.136 & 1.180 & 1.155 & 1.019 & 0.963 & 1.070 & 1.129 & 0.797 \\
No. of farms with CI $>1$ & 129 & 361 & 327 & 356 & 17 & 333 & 376 & 5 \\
No. of farms with CI $<1$ & 313 & 81 & 114 & 86 & 425 & 109 & 66 & 437 \\
\hline Source: author's calculations & & & & & & & &
\end{tabular}

Table 5: Distribution of farms according to year-to-year input biased technical change

\begin{tabular}{rrrrrrrrrrrrrr}
\hline & \multicolumn{1}{c}{ IBTCH } & \multicolumn{4}{c}{ Fertilizers vs. Seed } & \multicolumn{3}{c}{ Seed vs. Labour } & \multicolumn{3}{c}{ Fertilizers vs. Labour } \\
& $>1$ & $<1$ & $=1$ & F-using & S-using & N & S-using & L-using & N & F-using & L-using & N \\
\hline $1999 / 1998$ & 302 & 140 & 0 & 91 & 351 & 0 & 240 & 202 & 0 & 112 & 330 & 0 \\
$2000 / 1999$ & 229 & 213 & 0 & 239 & 203 & 0 & 229 & 213 & 0 & 227 & 215 & 0 \\
$2001 / 2000$ & 207 & 235 & 0 & 184 & 258 & 0 & 251 & 191 & 0 & 203 & 239 & 0 \\
$2002 / 2001$ & 279 & 163 & 0 & 383 & 59 & 0 & 167 & 275 & 0 & 349 & 93 & 0 \\
$2003 / 2002$ & 316 & 126 & 0 & 86 & 356 & 0 & 210 & 232 & 0 & 139 & 303 & 0 \\
$2004 / 2003$ & 306 & 136 & 0 & 324 & 118 & 0 & 291 & 151 & 0 & 332 & 110 & 0 \\
$2005 / 2004$ & 234 & 208 & 0 & 195 & 247 & 0 & 230 & 212 & 0 & 194 & 248 & 0 \\
$2006 / 2005$ & 229 & 213 & 0 & 272 & 170 & 0 & 294 & 148 & 0 & 329 & 113 & 0 \\
$2007 / 2006$ & 266 & 176 & 0 & 280 & 162 & 0 & 100 & 342 & 0 & 162 & 280 & 0 \\
Geomean & 260 & 175 & $\mathrm{x}$ & 205 & 189 & $\mathrm{x}$ & 214 & 212 & $\mathrm{x}$ & 212 & 195 & $\mathrm{x}$ \\
\hline Sorce: auther
\end{tabular}

Source: author's calculations

Table 6: Geometric means of input mix ratios and bias directions

\begin{tabular}{llllllll}
\hline & & \multicolumn{3}{c}{ Fertilizers vs. Seed } & \multicolumn{2}{c}{ Seed vs. Labour } & \multicolumn{2}{c}{ Fertilizers vs. Labour } \\
& IBTCH & F/S ratio & direction & S/L ratio & direction & F/L ratio & direction \\
\hline $1998-2007$ & 1.033 & 1.476 & F-using & 1.439 & S-using & 1.645 & F-using \\
$1998-2003$ & 1.070 & 1.938 & F-using & 2.052 & S-using & 1.740 & F-using \\
$2004-2007$ & 1.021 & 1.231 & F-using & 1.474 & S-using & 1.586 & F-using \\
\hline
\end{tabular}

Note: Years 1998-2003 represent EU pre-accession period, years 2004-2007 represent EU post-accession period.

Source: author's calculations

It employs a non-parametric distance function approach to measure Malmquist productivity index which is decomposed into technical efficiency change, scale efficiency change, and technical change. Technical change is further decomposed into technical change magnitude and input- and output-bias indices of technical change. Productivity change components provide more detailed information about character of productivity change itself and its sources. Our results indicate that productivity in the analysed sector decreased approximately by $20 \%$ within the examined period. Decrease in productivity was mitigated by technical efficiency improvement, what may indicate positive impact of competition. This improvement was driven mainly by pure efficiency improvement what could be understood as an economy of scale effect. The productivity decrease was caused mostly by worsening the technical change $(-42 \%)$, what may indicate deterioration of technology and lack of investment into the new technology. Components of technical change - 
indices of input- and output- bias of technical change were various from unity what suggests that technical change was Hicks' non-neutral. Detailed analysis of input bias of technical change shows that there is great variability of IBTCH and input bias orientation analysis in year-to-year development does not allow concluding on any using-saving pattern. In average for the whole sample period as well as for the pre-accession period, and post-accession period farms tend to apply fertilizersusing/seed-saving, seed-using/labour-saving, and fertilizers-using/labour-saving technical change bias.

Acknowledgments: This paper is made possible through support from the Slovak Scientific Grant Agency VEGA 1/0833/14 and VEGA 1/1213/12.

\section{REFERENCES}

BARTOŠOVÁ, D. - BARTOVÁ, L. - FIDRMUC, J. 2007. Agropotravinársky obchod Slovenskej republiky po vstupe do Európskej únie. Ekonomický časopis/Journal of Economics. Volume 55, 2007, No. 4: 327-344.

BARROS, C.P. - MANAGI, S. - MATOUSEK, R. 2009. Productivity growth and biased technological change: Credit banks in Japan. Journal of International Markets, Institutions \& Money. 19, 924-936. DOI: $\underline{10.1016 / \text { j.intfin.2009.07.006 }}$

BARROS, C.P. - WEBER, W.L. 2002. Productivity growth and biased technological change in UK airports. Transportation Research Part E 45, 642-653. DOI: 10.1016/j.tre.2009.01.004

CAVES, D.W. - CHRISTENSEN, L.R. - DIEWERT, W.E. 1982. The Economic Theory of Index Numbers and the Measurement of Input, Output, and Productivity. Econometrica 50:6, 1982, 1393-1414.

CHEN, PO-CHI - YU, MING-MIIN 2012. Total factor productivity growth and directions of technical change bias: evidence from 99 OECD and non-OECD countries. Ann Oper Res. DOI 10.1007/s10479-012-1087-4

FARRELL, M. J. 1957. The Measurement of Productive Efficiency, Journal of the Royal Statistical Society. Series A, General, 120, 253-81.

FÄRE, R., - GROSSKOPF, S. 1996. Intertemporal production frontiers: with dynamic DEA. Boston: Kluwer Academic

FÄRE, R. - GROSSKOPF, S. - LINDGREN, B. - ROOS, P. 1989, 1994. „Productivity Developments in Swedish Hospitals: A Malmquist Output Index Approach". In Charnes, A., Cooper, W.W., Lewin, A., Seiford, L. (eds) Data Envelopment Analysis: Theory, Methodology and Applications, Boston: Kluwer Academic Publishers

FÄRE, R. - GROSSKOPF, S. - LOVELL, C.A.K. 1985. The measurement of efficiency of production. Dordrecht: Kluwer-Nijhoff Publishing

FÄRE, R. - GROSSKOPF, S. - LEE, WEN-FU 2001. Productivity and technical change: the case of Taiwan. Applied Economics, 33:15, 1911-1925, DOI:10.1080/00036840010018711
FÄRE, R. - GROSSKOPF, S. - LOVELL, C.A.K. 1994. Production Frontiers. Cambridge University Press, New York.

FÄRE, R. - GRIFELL-TATJÉ, E. - GROSSKOPF, S. 1979. Biased Technical Change and the Malmquist Productivity Index. The Scandinavian Journal of Economics. Volume 99, Issue 1, p. 119-127

FOGARASI, J. - LATRUFFE, L. 2009. Farm performance and support in Central and Western Europe: A comparison of Hungary and France, 2009 Conference, August 16-22, 2009, Beijing, China 51431, International Association of Agricultural Economists. Available at: http://purl.umn.edu/51431

FULGINITI L.E., PERRIN, R.K. (1997). Ldc Agriculture: Nonparametric Malmquist Productivity Indexes. J Development Economics 53(2): 373-390.

GALANOPOULOS, K. - KARAGIANNIS, G. KOUTROUMANIDIS, T. 2004. Malmquist Productivity Index Estimates for European Agriculture in the 1990s. In Operational Research, vol. 4, 2004, No. 1, p. 73-91. DOI: 10.1007/BF02941097

LATRUFFE, L. - BRAVO-URETA, B.E. - MOREIRA, V. H. - DESJEUX, Y. - DUPRAZ, P. 2012. Productivity and Subsidies in the European Union: An Analysis for Dairy Farms Using Input Distance Frontiers, 2012 Conference, August 18-24, 2012, Foz do Iguacu, Brazil 126846, International Association of Agricultural Economists. Available at: http://purl.umn.edu/126846 LOVELL C. A. KNOX 2003. The Decomposition of Malmquist Productivity Indexes. Journal of Productivity Analysis. 20, 437-458, 2003. DOI: 10.1023/A:1027312102834

MPaRV SR 2000, 2003. Správa o pol'nohospodárstve a potravinárstve v Slovenskej republike za roky 2000 a 2003. Zelená správa. Výskumný ústav ekonomiky pol'nohospodárstva a potravinárstva. 2000, 2003.

SEKÁČOVÁ, Z., ŠŤASTNÝ, P., LAPIN, M. 2004. Extrémne prejavy počasia v roku 2003 na Slovensku. In: Rožnovský, J., Litschmann, T. (ed): Seminář „Extrémy počasí a podnebí“, Brno, 11. března 2004, ISBN 8086690-12-1. Available at: http://www.cbks.cz/sbornik04/prispevky/SEKACOVA.p $\underline{\mathrm{df}}$

SHEPHARD, R.W. 1970. The Theory of Cost and Production Functions. Princeton University Press

SIPILÄINEN, T. - KUMBHAKAR, S.C. 2010. Effects of direct payments on farm performance: The case of dairy farms in northern EU countries. University of Helsinki, Department of Economics and Management. Discussion Papers, n. 43, Helsinki, 2010. Available at: http://www.helsinki.fi/taloustiede/Abs/DP43.pdf

SIPILÄINEN, T. - RYHÄNEN, M. 2005. Technical change in Finnish grass silage. Agricultural and Food Science. Vol. 14 (2005): 250-263. DOI: $10.2137 / 145960605775013209$

WU, S. - WALKER, D. - DEVADOSS, S. - LU, Y. 2001. Productivity Growth and its Components in Chinese Agriculture after Reforms. In. Review of Development Economics. 5(3), 375-391. DOI: $\underline{10.1111 / 1467-9361.00130}$ 
Appendix 1 Descriptive statistics of the data, 1998-2007

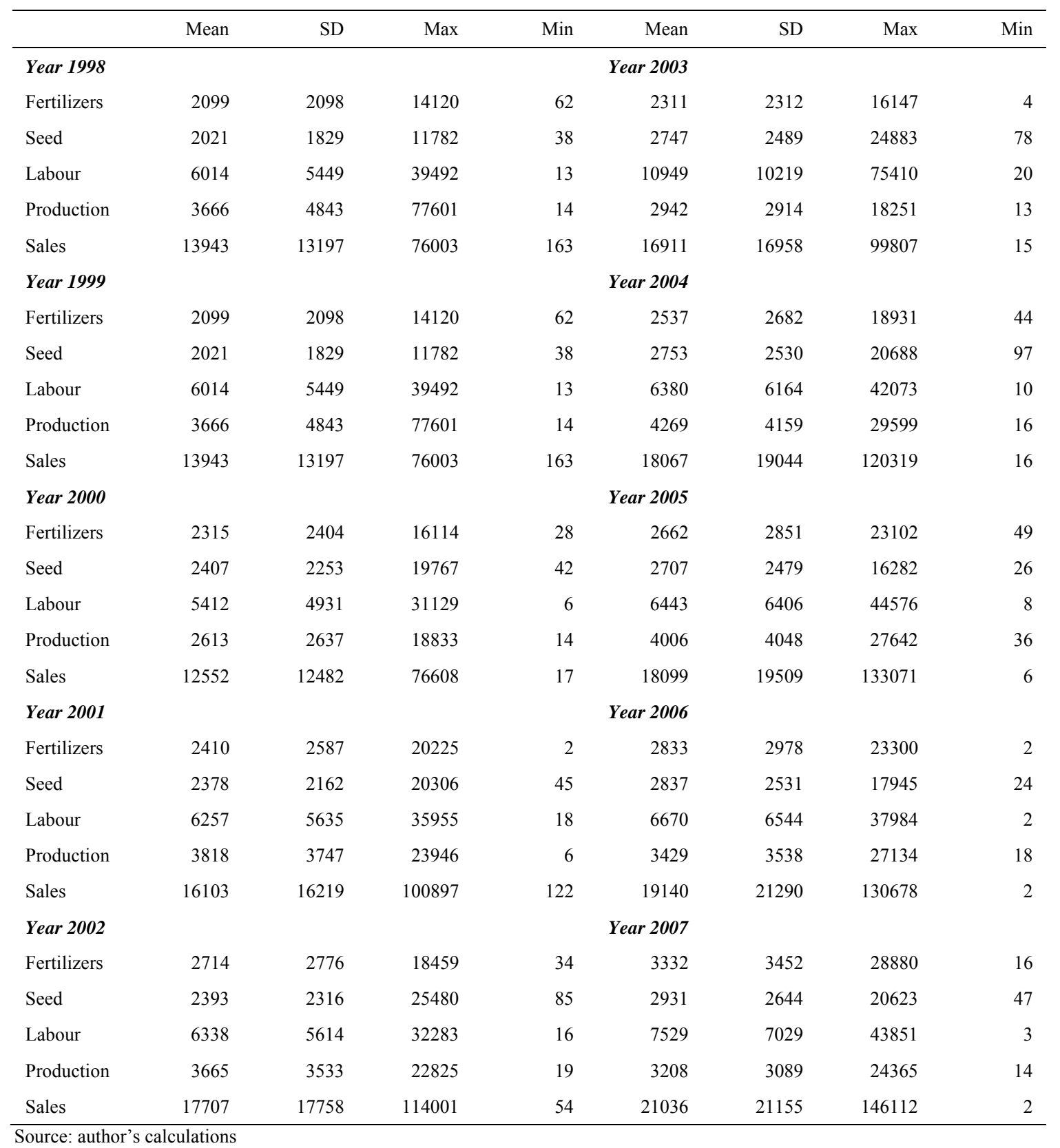

